\title{
CEO Bonus and Fair Value Accounting: Evidence from US Business Combination Rasha Mohamed Nasseem Elbolok
}

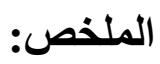

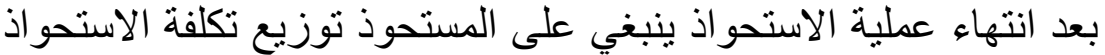

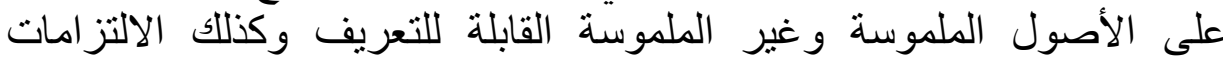

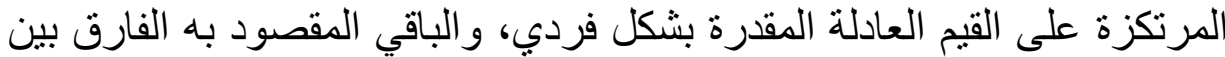

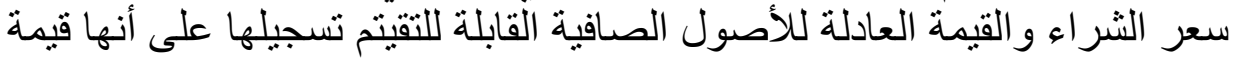

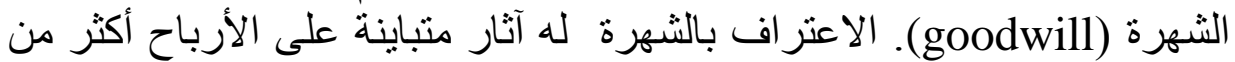

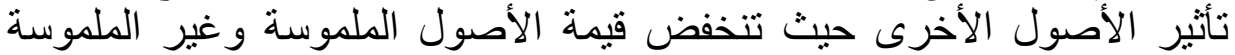

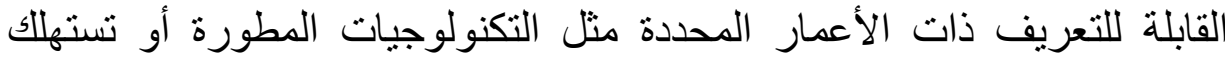

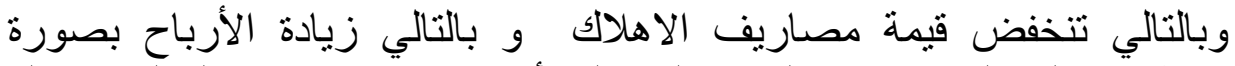

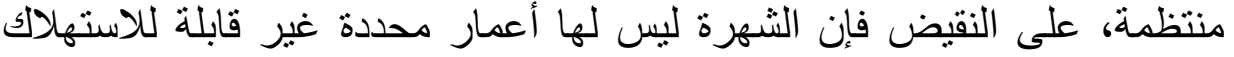

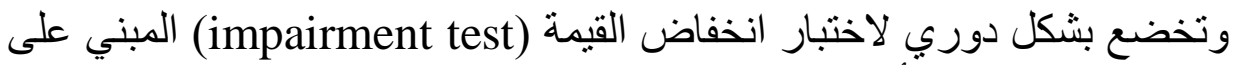

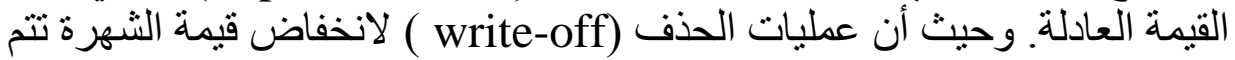

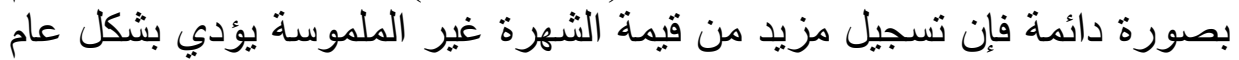
إلى زيادة أرباح ما بعد الاستحو اذذان.

بالنظر إلى آثار تلاك الأرباح على راتب الرئيس التنفيذي، فلقد توصلت

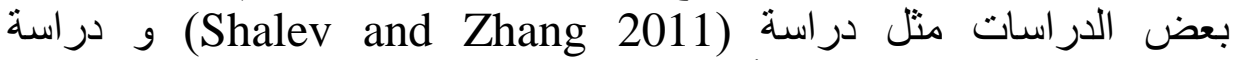
(Huang et al. 2010)

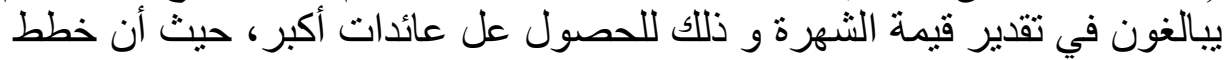

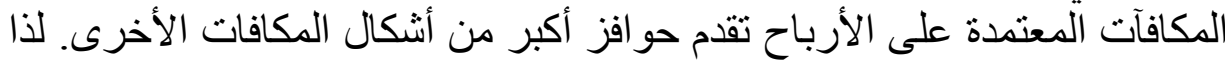

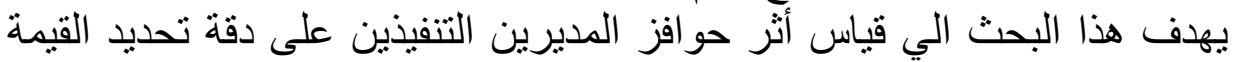

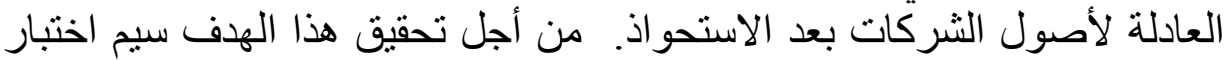

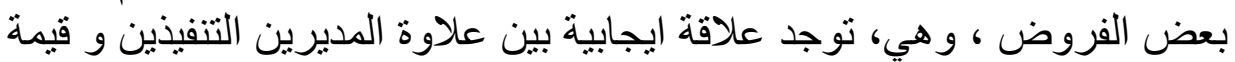

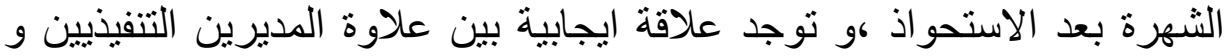

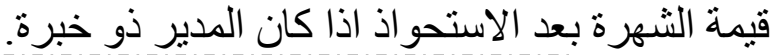




\section{CEO Bonus and Fair Value Accounting: Evidence from}

\section{Abstract:}

This study investigates the role executive compensation structure plays in post-acquisition fair value measurement of goodwill at Purchase Price Allocation (PPA). It examines the relationship of CEO earning based (bonus) with the amount recognized as goodwill after mergers and acquisitions. Also, the study investigates the effect of CEO characteristics such as gender, age and tenure on goodwill recognition. After SFAS 142 is applied in 2002, goodwill required to be impaired based on fair value estimates instead of being amortized like other identifiable intangible assets. This may lead CEOs to report more goodwill to avoid depreciation cost and thus increase reported income and consequently their bonus. Using a sample of 110 public U.S business combinations completed in the service sector between 2002 and 2015; first, the researcher finds that the relationship between CEO bonus and the amounts recognized as goodwill is not linear but correlates only if he/she has longer tenure. Also, results indicate negative relationship between higher representation of CEO male and goodwill. Overall, findings indicate that executive compensation structure affects the fair value accounting for acquired assets and liabilities after a business combination. This study is the first to test for the impact of CEO bonus on fair value measurement of goodwill in U.S context specifically in the service sector industry and also, shed the light on CEO tenure interaction effect on goodwill recognition.

Keywords: CEO. Executive Compensation, Fair Value, Mergers, Acquisitions, Bonus, Goodwill. 


\section{CEO Bonus and Fair Value Accounting: Evidence from ......

\section{Introduction}

This study develops empirical research to explore the relationship between executive compensation structure and fair value accounting in the context of business combination. Particularly, it examines the effect of CEO earning based compensation on post-acquisition fair value measurement on merger and acquisition activities completed in U.S. context, after the application of the Statement of Financial Accounting Standards "SFAS" 142, Goodwill and Other Intangibles Assets, in July 2001, using the amounts recognized as goodwill as a proxy of the accuracy of fair value accounting. Specifically, the researcher examines the impact of CEO bonus compensation on the amount recognized as goodwill after an acquisition.

Some researchers critique SFAS 142 from several perspectives which provides an opportunity for research. Motivated by the post SFAS 142 debate on the accounting for intangible assets, this study investigates the allocation of purchase price between goodwill and other assets, the initial valuation of these acquired assets, upon the completion of a merger or an acquisition and how it can be affected by the executive compensation structure. This study focuses on the Purchase Price Allocation (PPA) practice in order to examine the accounting consequences of executive compensation 


\section{CEO Bonus and Fair Value Accounting: Evidence from} Rasha Mohamed Nasseem Elbolok

structure for some reasons. First, there is increasing movement from the accounting standards setters and the SEC towards fair-value-based purchase price allocation and the related probable misallocation of the purchase price between assets. Second, the important impact of the merger and acquisitions decisions on the financial reporting consequently makes the purchase price allocation an economic significance process to detect the influence of several reporting incentives. It also provides a distinctive opportunity for examining how CEO incentives affect fair value measurement for assets and liabilities. The third reason is the limited empirical evidence on fair value measurements and its link to executive compensation structure.

Although there are different studies that discuss fair value in general, there are few studies that discuss the relationship between executive compensation structure and fair value accounting in case of merger and acquisition. Considering the prior literature, this study contributes to the nascent but growing literature on post-acquisition fair value measurement in several ways. First, the study takes into consideration the industry effect on goodwill accounting by using data on service sector companies. This is because per the nature of operation of service industry, companies generate a greater amount of intangible assets than property plant and equipment. As a result, service companies' decisions 


\section{CEO Bonus and Fair Value Accounting: Evidence from} Rasha Mohamed Nasseem Elbolok

about intangible assets including goodwill are more influential than other industries. Hence, the service industry is considered for this study. Second, the use of the process model in the study is more impressive, influential, and more helpful to understand not only the relationship between $\mathrm{X}$ and $\mathrm{Y}$ but also how and when that relationship holds (whether directly or in the presence of a moderating variable) and whether the relationship is strong or weak.

The overall aim of this study is to examine the relationship between executive compensation structure and fair value accounting on business combination context. In order to achieve the stated aim, some objectives have been identified. These are as follows:1. Studying the historical background of executive managers' compensation and factors affecting it. 2. Identifying fair value accounting, the debate around, and its role after merger and acquisition. 3. Measuring the impact of the CEO bonus compensation on the accounting for goodwill, and exploring the effect of CEO characteristics on goodwill recognition.

The design of the methodology used in the study has established to be suitable for providing answers for the research questions and testing the research hypotheses. Different databases are used to collect data from the U.S. context. Actually, Data about purchase price allocation and 


\section{CEO Bonus and Fair Value Accounting: Evidence from} Rasha Mohamed Nasseem Elbolok

goodwill are hand collected from the Securities and Exchange Committees (SEC) website specifically from the Electronic Data Gathering, Analysis, and Retrieval (EDGAR). Also, data from public acquirers and targets are collected from Wharton Research Data Services (WRDS) database in the Compustat Fundamental annual files to create a sample of information about the acquisition and the economic determinants of goodwill. The sample is taken from Securities Data Companies (SDC) platinum merger and acquisition from 2002 to 2015. The information about CEO bonus, tenure, gender, and age is collected from the Exec Comp database. Then, the study uses SAS statistical program to merge the tables of data from different databases and for the regression model using the multivariate analysis test. In addition, this study employs SPSS statistical program, specifically the Process Model, to test for the interaction term of some variables and test for their role as a moderating variable of $\mathrm{CEO}$ tenure.

The remainder of the paper is structured as follows. The second section reviews the literature on the topic and introducing the hypotheses of the study. The third section presents the research design and methodology. The fourth one presents and discusses the results while the last one concludes and providing further developments of the research. 


\section{CEO Bonus and Fair Value Accounting: Evidence from}

\section{Literature Review and Hypothesis Development}

\subsection{Literature Review:}

Goodwill resulted from acquisitions which calculated as the difference between purchase prices and fair value of net acquired assets is of prime interest. Stabler (2013) views that implications of goodwill recognition are of significant importance for the future of a business. Goodwill treatment is different from other sorts of tangible and intangible assets because it requires periodic fair-value-based impairment tests. Write-offs of goodwill is unamortized and subject to a periodic fair-value test that leads to higher post-acquisition earnings. CEO is always inclined to overstate goodwill because the bonus plans that are earning based further motivate CEOs to overstate goodwill so that they may become able to earn more. Bonus plans are often determined by mechanical based formulas that give different factors appropriate weights. Compensations of CEOs are affected by the misallocation of goodwill as they are strongly related to contract on earnings and for that reason those are very likely to increase with high inflation in earnings.

Compensation consists of two main components; bonus and equity. Bonuses have more significant impact on earnings as an accounting related pay compared to other components. It has also been observed that significance of cash compensation 


\section{CEO Bonus and Fair Value Accounting: Evidence from}

has been increased in the past decade. Accounting consequences of bonus intensity and bonus performance are also related to purchase price allocations. Shalev et al. (2011) are of the view that here is positive relationship between bonus intensity and allocation of goodwill and it becomes less likely to be there when cash flow methods are utilized. They found that the association between bonus intensity and overstatement of goodwill by CEO and top management of the company is proven to be declined along with cash flows, sales, earnings, that are most commonly used measures of performance. Different managerial incentives determine bonus plans for the purpose of purchase price allocation. Some measures like cash flows and sales don't affected by the overstatement of goodwill while others are different like earning growth which they are associated with future treatments. Overstatement become an expensive alternative and is less likely to be there in future periods when cash flows and sales are used as measures of performance. In addition to accounting performance measures there are many other factors that may contribute to mitigate level of motivation for CEO to overstate goodwill.

It can be said that few studies provide contribution on the misallocation of goodwill especially the over allocation of goodwill by the CEO parts in order to increase their own compensations. For example, Shalev et al. (2011) examined 


\section{CEO Bonus and Fair Value Accounting: Evidence from} Rasha Mohamed Nasseem Elbolok

executive compensation and goodwill recognition under US GAAP while Detzen and Zulch (2012) analyze this relation in an environment that based on International Financial Reporting Standards (IFRS). On one hand, Shalev et al. (2011) find, based on a sample of 184 acquisitions completed between July 2001 and April 2007, that in the post-SFAS 141 period CEOs whose compensation packages depend heavily on earnings-based bonuses are more likely to over allocate the purchase price to goodwill because the over allocation likely increases post-acquisition earnings and bonuses while on the other hand Detzen and Zulch (2012) examine the relation between CEO's bonuses and goodwill recognition in European IFRS post mergers and find that CEOs whose compensation packages depend heavily on cash bonus intensity (the percentage of the bonus over the total cash compensation) are more likely to over allocate the purchase price to goodwill and limit this relation if the CEO's bonuses represent $150 \%$ to $200 \%$ of the base salary. Also, Bugeja and Loyeung (2014) examine the relation between CEO's bonuses and goodwill recognition in Australia after adopting IFRS using a hand collection data on goodwill recognized for 308 takeovers happened between 1998 and 2012. Their results support the previous studies as it indicates that the amount recorded as goodwill is positively associated with the use of cash payment. They find that the economic characteristics of 


\section{CEO Bonus and Fair Value Accounting: Evidence from}

the bidding and the target don't explain the amount recorded as goodwill. Boennen and Glaum (2014) comprises the empirical literature on goodwill accounting since the introduction of SFAS 141, SFAS 142 and IAS 36 trying to find some fields for future research on goodwill accounting. The study includes in details four main areas of research on goodwill accounting which are purchase price allocation and determination of goodwill resulted from the acquisitions, the treatment of goodwill including value relevance and predictive value, measurement of goodwill (goodwill impairment), and finally summarize the findings from previous literature on the effect of earnings management on goodwill accounting.

\subsection{Hypotheses Development}

\subsubsection{CEO bonus and the amount of goodwill}

Since SFAS 142 Goodwill and Other Intangible Assets, became effective in July 2001, it addresses how the accounting treatment for goodwill post acquisitions differs from that for other assets. Goodwill is not amortized but subject to periodic fair value based impairment tests. Thus, while the recognition of most tangible and identifiable intangible assets depresses post-acquisition earnings on a regular basis, recording goodwill does not, unless a goodwill impairment write-off has to be recorded. Li and Sloan (2015) examine the effect of this standard on the accounting and 


\section{CEO Bonus and Fair Value Accounting: Evidence from} Rasha Mohamed Nasseem Elbolok

valuation of goodwill. They find that as a result of the discretion afforded by SFAS 142, managers delay goodwill impairments. This causes earnings and stock prices to be temporally inflated.

Many researchers try to examine the effect of CEO bonus on the purchase price allocation after the combination. They focus on the amount recognized as goodwill in the acquirer accounts. For example, Shalev et al. (2011) examine how compensation structures affect the accounting for business combination in U.S. They assume that, since the initial valuation of goodwill and other assets affects postacquisition earnings differently, CEOs are motivated to increase the amount of recorded goodwill in order to reduce future depreciation and amortization expenses, thereby increasing earnings and bonuses. They expect that CEO's incentive to over-allocate goodwill becomes stronger as the relative importance of CEO bonus in his/her pay package increases. Also, Detzen and Zulch (2012) examine how compensation structures affect the accounting for business combination but on the European context. They state that managers may wish to make use of the flexibility regarding goodwill depending on their accounting policies. They may want to avoid amortization charges for their personal benefit given the importance of accounting earnings for determining executive compensation. They examine whether or not CEOs 


\section{CEO Bonus and Fair Value Accounting: Evidence from}

tend to increase the amount of goodwill recognized in acquisitions if their pre-acquisition cash compensation depends largely on bonuses, possibly to further increase their remuneration. Another study by Hamberg et al. (2011) made on a Swedish sample and find that the amount of goodwill recognized in acquisitions has increased substantially after Swedish firms adopted IFRS 3 . They find that companies with large amounts of goodwill yield abnormal returns and conclude that investors view the increase in earnings due to lower or no goodwill amortization charges as an indication of higher future cash flows. Based on the above discussions, it suggests that CEOs whose annual pay depends mainly on bonuses are likely to benefit more from the overstatement of goodwill. Thus, the first testable hypothesis is:

H1: After an acquisition, there is a positive relationship between the amounts recognized as goodwill and CEO bonus compensation.

\subsubsection{Bonus Compensation and Goodwill Moderated by CEO Tenure:}

Prior literature has shed the light on the role CEO tenure plays in the field of accounting in two ways. On one hand, several studies investigate the relationship between executive tenure and financial reporting accounting including earning management and goodwill impairment. For example, Viśnevskaá (2010) found that CEOs' tenure is significantly 


\section{CEO Bonus and Fair Value Accounting: Evidence from} Rasha Mohamed Nasseem Elbolok

associated with the financial reporting behavior of the company. Another study by Bengtsson et al. (2007) investigated the occurrence of earnings management (accruals and write-off) in Sweden, surrounding management turnovers. They found that earnings were reduced in the first year of the turnover and increased in the following year. Beatty and Weber (2005) hypothesized that the departure of the CEO who made the original acquisition decision can explain the difference between actual and predicted goodwill write-offs. Also, Ramanna and Watts (2007) found that goodwill write offs are negatively associated with CEO tenure. Another study by Zang (2008) found that recent management change was an explanatory variable for earnings management through transitional goodwill impairment losses. This is because he believed that higher goodwill impairment losses were taken during the transitional period to increase the likelihood of higher earnings in the future. Masters-Stout et al. (2007) performed a subsequent study, which related goodwill impairments under SFAS 142 to CEO tenure. For the companies that did impair, they found that newly appointed CEOs reported higher impairments than senior CEOs. The relationship between CEO tenure and goodwill accounting can be explained from the previous literature as follows: First, CEOs with longer tenure are more concerned about their 


\section{CEO Bonus and Fair Value Accounting: Evidence from} Rasha Mohamed Nasseem Elbolok

reputation as an M\&A expertise and have greater power within their firm that is strongly associated to both financial reporting behavior of the company and to the magnitude of goodwill recognition and impairment. They tend to recognize more good to show higher income and higher company performance which is in favor of their reputation. Second, CEOs with longer tenure who are closer to retirement are no longer concerned with career development and care less about the company future which may lead them to recognize more goodwill now regardless of the impairment losses associated with the future. On the other hand, literature examines the role of CEO tenure on his/her compensation. For example, Cremersa and Paliab (2011) study how the CEO pay level and pay-performance sensitivity vary with his/her tenure in the firm. They document a positive association between tenure and CEO pay levels. Also, Zheng (2010) study the effect of tenure on the structure of CEO compensation. He finds that the percentage of equity-based compensation increases during the early years of tenure for outside CEOs, and decreases during the later years of tenure for inside CEOs. Darrough et al. (2012) examine whether the decrease in CEO compensation in response to goodwill impairment losses differs for firms that have longer-tenured CEOs compared to those that have shorter tenure CEOs. From the above 


\section{CEO Bonus and Fair Value Accounting: Evidence from} Rasha Mohamed Nasseem Elbolok

mentioned literature, it can be said that CEOs tenure affects their compensation and also their decisions about goodwill recognition. It can also play a moderating role between $\mathrm{CEO}$ compensation (bonus) and goodwill. Therefore, the following hypothesis will be tested:

H2: After an acquisition, CEO with bonus compensation tends to overstate the amount of goodwill if he/she has longer tenure.

\section{Research Design and Methodology}

\subsection{Sample Description}

The analysis is based on a sample of 110 US services firms over the period 2002-2014. The Year 2002 is chosen as the start date of the research sample because companies are required to disclose the allocation of purchase price since SFAS 142 became effective in July 2001.Both the acquirer and the target are required to be US publicly traded in order to obtain their financial and stock price data. Then all the merged and acquired firms are required to be in the same industry specifically the service sector (SIC code from 7000 to 8990). Different databases are used to collect data of the study including; SDC, SEC (EDGAR), WRDS (Compustat and ExecuComp).

The researcher uses the SAS statistical program to 


\section{CEO Bonus and Fair Value Accounting: Evidence from}

merge the tables of the data from different sources to reach the final table of all the data required for the final sample. The research final sample consists of 110 firm year observations of service firms from the period 2002 to 2015 used in the univariate analyses as the final or full sample.

\subsection{Methodology:}

- To test H1, the researcher follows the regression model constructed by Detzen and Zulch (2012):

$$
\begin{aligned}
G W=\alpha_{0} & +\alpha_{1} \text { Bonus Ratio }+\alpha_{2} \text { SYNERGY } \\
& +\alpha_{3} \text { TRG.BTM }+\alpha_{4} \text { STOCK }+\alpha_{5} \text { SIZE } \\
& +\alpha_{6} \text { Acq.MTB }+\alpha_{7} \text { Gender }+\alpha_{8} \text { Tenure } \\
& +\alpha_{9} \text { Age }+\in(2)
\end{aligned}
$$

\section{Where:}

GW is the amounts of goodwill recognized after an acquisition and disclosed in the acquirer balance sheet in the purchase price allocation setting divided by the total purchase price. Bonus Ratio is the CEO bonus over total compensation averaged over three years up to the acquisition announcement date. Synergy the fair value of the expected gains from the combination for both the acquirer and the target. Tgt BTM is the the fair value of the 'going concern' element of the target or the ability of the target to earn a higher rate of return from the combination of net assets than from those operating separately in the market. Stock is a dummy variable that take the value of 1 or 0 if the acquirer paid for the acquisition by 


\section{CEO Bonus and Fair Value Accounting: Evidence from} Rasha Mohamed Nasseem Elbolok

stocks (even partially) or totally in cash respectively. It is a proxy for the acquirer overpayment. Size refers to the target size related to the acquirer and calculated by dividing the total purchase price over the acquirer's total pre-acquisition assets (one year before the acquisition announcement date). The researcher argues that higher size ratio means large amounts are paid by the acquirer to purchase the target which highly affect the acquirer balance sheet and lead the manager to highly examine the acquisition to avoid the overpayment. Acq. MTB refers to the acquire market to book ratio of equity one year before the acquisition announcement year. Following Zhang and Zhang 2007, the researcher argues that acquirers with higher MTB ratio who can recognize better targets to generate higher synergies and growth record more goodwill to reflect the unrecognized growth options of the target. Gender is a dummy variable that take the value of 1 or 0 if the acquirer CEO is male or female respectively. Tenure is the CEO's number of years of work with the acquirer's company. Age is the CEO age at the acquisition announcement year.

- To test $\mathrm{H} 2$, the researcher constructs the following regression model:

$$
\begin{aligned}
G W & =\alpha_{0}+\alpha_{1} \text { BORATIO }+\alpha_{2} \text { TNBONUS } \\
& +\alpha_{3} \text { SYNERGY }+\alpha_{4} \text { TRG.BTM }+\alpha_{5} \text { STOCK } \\
& +\alpha_{6} \text { SIZE }+\alpha_{7} \text { ACQ.MTB }+\alpha_{8} \text { Gender } \\
& +\alpha_{9} \text { AGE }+\in(3)
\end{aligned}
$$

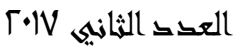




\section{CEO Bonus and Fair Value Accounting: Evidence from}

\section{Where:}

TNBONUS is the interaction term of the CEO tenure multiplied by the CEO bonus.

\section{Results and Discussion}

The researcher first conducts a univariate analysis for the full sample. Then, to examine the multi-collinearity between the explanatory variables, Pearson's correlations are calculated for the variables. Multicollinearity appears not to be an issue.

\subsection{CEO Bonus and Goodwill Recognized}

This model extends the model capture the economic determinants of goodwill by including Bonus Ratio Bonus is the key independent variable and is calculated as the ratio of CEO bonus compensation over total compensation averaged over three years up to the acquisition announcement date starting 2 years before the acquisition announcement date. I run the model based on 108 observations, using multiple linear regression model. The results presented below in table 1 (panel $\mathrm{A}$ and $\mathrm{B}$ ) show that the overall regression model is significant $\mathrm{F}=4.064, \mathrm{P}<0.001$. Adjusted $\mathrm{R}$-square of $20.5 \%$ is obtained. Bonus has positive non-significant relationship with goodwill with a coefficient of 0.18 and p-value of 0.896 . The results are quite different from the literature review that finds positive significant relationship between CEO bonus and 


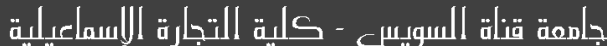

CEO Bonus and Fair Value Accounting: Evidence from ......

Rasha Mohamed Nasseem Elbolok

the amount recognized as goodwill. The results of the bonus model don't confirm the study hypothesis H1: "After an acquisition, there is a positive relationship between the amounts recognized as goodwill and $\mathrm{CEO}$ bonus compensation."

\section{Table 1: Multiple Regression Results for H1}

\section{PANEL A: Regression Model (1)}

$$
\begin{aligned}
\boldsymbol{G W}=\alpha_{0}+ & \alpha_{1} \text { Bonus Ratio }+\alpha_{2} \text { SYNERGY } \\
& +\alpha_{3} \text { TRG.BTM }+\alpha_{4} \text { STOCK }+\alpha_{5} \text { SIZE } \\
& +\alpha_{6} \text { Acq.MTB }+\alpha_{7} \text { Gender }+\alpha_{8} \text { Tenure } \\
& +\alpha_{9} \text { Age }+\in
\end{aligned}
$$

PANEL B: Estimation of Regression Model, $\mathrm{N}=108$ $(\mathbf{F}=4.064, \mathbf{P}<0.001, \mathbf{R}$-square $=0.272$, Adj R-Square $=$ $0.205)$

\begin{tabular}{|ccccc|}
\hline Variable & $\begin{array}{c}\text { Predict } \\
\text { ed Sign }\end{array}$ & $\begin{array}{c}\text { Coefficie } \\
\text { nt }\end{array}$ & $\begin{array}{c}\text { T- } \\
\text { Statisti } \\
\text { cs }\end{array}$ & $\begin{array}{c}\text { P- } \\
\text { value }\end{array}$ \\
\hline INTERCEPT & & 1.705 & 2.573 & 0.012 \\
BONUS RATIO & + & 0.180 & 0.131 & 0.896 \\
& + & 0.138 & 1.713 & $\mathbf{0 . 0 9 0}$ \\
SYNERGY & + & & & $*$ \\
\hline
\end{tabular}


CEO Bonus and Fair Value Accounting: Evidence from Rasha Mohamed Nasseem Elbolok

\begin{tabular}{|c|c|c|c|c|}
\hline TRG BTM & + & 0.026 & 0.606 & 0.546 \\
\hline STOCK & + & 0.019 & 0.177 & 0.860 \\
\hline \multirow[t]{2}{*}{ SIZE } & \multirow[t]{2}{*}{-} & \multirow[t]{2}{*}{-0.248} & \multirow[t]{2}{*}{-2.404} & $\begin{array}{c}0.018 \\
* *\end{array}$ \\
\hline & & & & $\begin{array}{c}\mathbf{0 . 0 5 0} \\
* *\end{array}$ \\
\hline АС МТВ & - & -0.044 & -1.980 & \\
\hline Gender & - & -1.600 & -5.378 & 0.000 \\
\hline Tenure & + & 0.001 & -0.032 & $* * *$ \\
\hline \multirow[t]{2}{*}{ Age } & + & 0.004 & 0.416 & 0.975 \\
\hline & & & & 0.678 \\
\hline $\begin{array}{c}\text { Number of } \\
\text { Observations }=108\end{array}$ & & & & \\
\hline
\end{tabular}

Dependent Variable: GW

\subsection{CEO Bonus and Goodwill Recognized moderated by CEO tenure}

In model (2) as shown below in table 2 Panel A and B, I include an interaction term of bonus and tenure. Tenure is a moderating variable (M) between CEO bonus and goodwill. I hypothesize that bonus is positively related to goodwill only if the CEO has longer tenure or in other words if the average years of being CEO in the acquirer company is large.

Based on 108 observations, I run the test using the process model in SPSS (using model 1). Results shows that the model is significance at $5 \%$ level with $\mathrm{F}=4.3157, \mathrm{P}=$ 


\section{CEO Bonus and Fair Value Accounting: Evidence from}

0.000 , and R-Square of $30.7 \%$. the interaction is significant at $5 \%$ level with a $\mathrm{p}$ value $=0.0267$, coefficient of 0.48 and $\mathrm{t}=2.25, \mathrm{R} 2$ change by $3.61 \%$ with $\mathrm{F}=5.063$. Results separated into three tenure levels showing that bonus and goodwill are only significant at level 3 where CEO tenure is 17 years where $\mathrm{P}=0.04$ (5\% significance level). Results of model 3 confirm the hypothesis $\mathrm{H} 2$ stating that: After an acquisition, there is a relationship between the amounts recognized as goodwill and CEO bonus compensation, if the CEO is highly tenured.

Model (3) adds to model 1 and 2 that synergy is positively related to the amount recognized as goodwill with a coefficient of $16.89 \%, p$-value $=0.03 \quad(5 \%$ level of significance), and $\mathrm{t}=2.11$ ). The coefficient indicates that for every one-unit increase in synergy, goodwill recognition increase by about $17 \%$. The same as model 1 and 2 , model 3 reports the significance of SIZE where $\mathrm{p}=0.01 \quad(5 \%$ significance level) and negative coefficient of $28.7 \%$, Acquirer MTB, is negative (0.436) but insignificant (t-statistic $=-2.01 ; \mathrm{P}$-value $=0.04)$, and GENDER where $\mathrm{P}=0.00(1 \%$ significance level) and negative coefficient of 1.59.

\section{Table 2: Multiple Regression Results for $\mathrm{H} 2$}

$$
\begin{gathered}
\text { PANEL A: Regression Model (2) } \\
G W=\alpha_{0}+\alpha_{1} B O R A T I O+\alpha_{2} \text { TNBONUS } \\
+\alpha_{3} S Y N E R G Y+\alpha_{4} \text { TRG.BTM }
\end{gathered}
$$




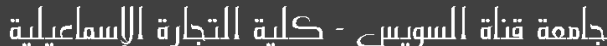

CEO Bonus and Fair Value Accounting: Evidence from ...... Rasha Mohamed Nasseem Elbolok

$$
\begin{gathered}
+\alpha_{5} S T O C K+\alpha_{6} S I Z E+\alpha_{7} A C Q . M T B+\alpha_{8} \text { Gender } \\
+\alpha_{9} A G E+\in
\end{gathered}
$$

\section{PANEL B: Estimation of Regression Model, $\mathrm{N}=108$ $(\mathbf{F}=4.3157, \mathbf{P}=0.0001, \mathbf{R}=0.554, \mathbf{R}$-square $=0.307)$}

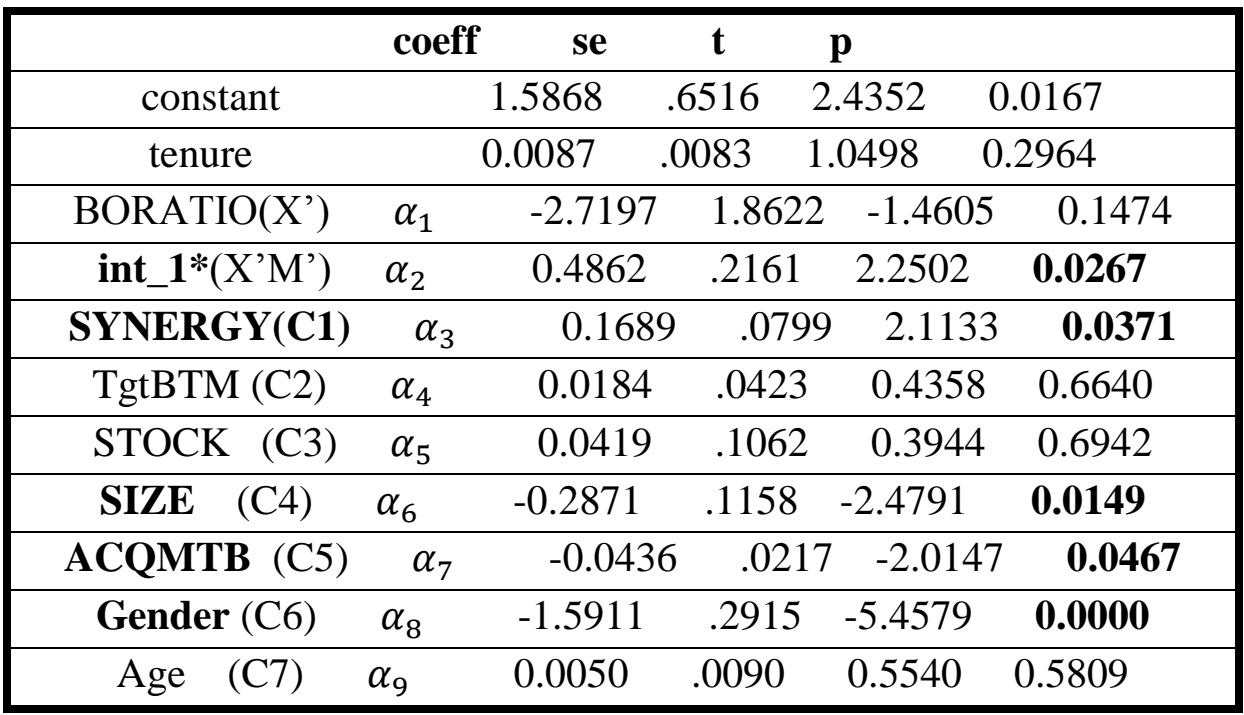

* This Table Presents Results from A Regression Analysis Examining the Moderation of the Effect of CEO Bonus on Goodwill Recognition by CEO Tenure, controlling for Synergy, Target book to market ratio, Stock, Size, Acquirer market to book ratio, Gender, and, Age.

*int_1 = BORATIO X tenure.

$* \mathrm{R}^{2}$ increase due to interaction by $3.61 \%$. 
CEO Bonus and Fair Value Accounting: Evidence from Rasha Mohamed Nasseem Elbolok

Conditional Effect of $\mathrm{X}$ on $\mathrm{Y}$ at Values of the Moderator (s):

\begin{tabular}{|c|c|c|c|c|}
\hline tenure & & & e & $\mathbf{p}$ \\
\hline 0.0000 & -2.7197 & 1.8622 & -1.4605 & 0.1474 \\
\hline 7.9259 & 1.1336 & 1.4096 & 0.8042 & 0.4232 \\
\hline 16.8154 & 5.4553 & 2.7025 & 2.0186 & 0.0463 \\
\hline
\end{tabular}

\section{Conclusions and Limitations of the Study}

Based on the results of this research it can be concluded that goodwill represents a large portion of service sector companies' financial statements and thus strongly affects their financial position and decisions. Moreover, Synergy expected from the acquisition, the target size, and acquirer market to book ratio are considered the most important economic determinants of goodwill valuation in the service sector. In accordance with the above discussed idea, this study This study examines the relationship between executive compensation structure and post-acquisition fair value measurement. Specifically, it examines the relationship between CEO bonus and goodwill recognition after merger and acquisition of US service companies since the application of SFAS (142) from 2002 to 2015.The results provide support for two hypotheses at different levels of significance.

First, this study hypothesizes that CEOs with higher bonus ratio from total compensation recognize more goodwill in the purchase price allocation. On examination of this 


\section{CEO Bonus and Fair Value Accounting: Evidence from} Rasha Mohamed Nasseem Elbolok

hypothesis, the study finds that there is no direct relationship between bonus and goodwill. This finding is unlike prior literature (Shalev et al. 2013 and Detzen and Zulch 2012) probably because of some reasons enumerated below: a) This study is applied only in the service sector which already has higher goodwill amounts, as results indicate that $56 \%$ of the sample recognize 51- to- $100 \%$ of goodwill after the acquisition. This may be a reason why there is no room for CEO to overestimate the amount of goodwill. b) The sample studied has lower bonus ratio with a mean of 0.03 while having higher equity-based compensation with a mean of 1.21. This implies that CEO may focus on long-term incentives rather than short-term bonuses.

Second, on examination of the second hypothesis, the findings show that CEO with bonus compensation tend to manipulate the amount recognized as goodwill only if he/she has a long tenure of 8 to 17 years. This finding supports prior research on the existence of CEO tenure as a proxy for the reputation component of goodwill decisions (Ramanna and Watts 2012). On the one hand, CEOs with longer tenure are more concerned about their reputation as an M\&A expertise and have greater power within their firm. This is strongly associated with financial reporting behavior of the company and strongly associated with the magnitude of goodwill recognition and impairment. They tend to recognize more 


\section{CEO Bonus and Fair Value Accounting: Evidence from Rasha Mohamed Nasseem Elbolok}

goodwill to show higher income and higher company performance which is in favor of their reputation. In addition, CEOs with longer tenure who are closer to retirement are no longer concerned with career development and care less about the company's future. This may lead them to recognize more goodwill in the present period regardless of the impairment losses associated in the future.

This study has some limitations; first, because of data collection issues, the sample size is relatively small. After merging and cleaning the data, I end with only 108 merger and acquisition deals. This implies that the generalization of the results requires some cautions. The second limitation is having the sample for the years $2002-2015$. The start of the research sample had begun in 2002 because companies are required to disclose the allocation of purchase price since SFAS 142 became effective in July 2001. Although this period includes the financial crisis era in 2007 and 2008, this may affect both the number of M\&A completed and the executive compensation pay. The third limitation is because of the variety of the executive compensation structure; the study could not cover all of the components of executive compensation but just focused on bonus. 


\section{References:}

- Boennen S., and Glaum M. (2014), "Goodwill accounting: A review of the literature", Working Paper.

- Bugeja, M., and Loyeung A. (2014). Acquisition date goodwill: determinants and market reaction. Working Paper.

- Carvalho, C., Rodrigues, A. M., \& Ferriera, C. (2015). The Recognition of Goodwill and Other Intangible Assets in Business Combinations - The Portuguese Case. Australian Accounting Review, 26(1), 4-20.

- Darrough, M. N., Guler, L., \& Wang, P. (2014). Goodwill Impairment Losses and CEO Compensation. Journal of Accounting, Auditing and Finance, 29(4).

- Detzen, D., \& Zülch H., (2012). Executive compensation and goodwill recognition under IFRS: Evidence from European mergers. Journal of International Accounting, Auditing, and Taxation, 21(2),106-126.

- Devers, C. E., McNamara, G., Haleblian, J., \& Yoder, M. E. (2013). Do they walk the talk? Gauging acquiring CEO and director confidence in the value creation potential of announced acquisitions. Academy of Management Journal, 56(6), 16791702.

- Jarque, A. (2014, May). The Complexity of CEO Compensation: Incentives and Learning. In 2014 Meeting Papers (No. 1355). Society for Economic Dynamics.

- Jing-hao, C. (2010). The Influence Produced by the Fair Value Measurement on Managers' Salary. Journal of Guizhou Commercial College, 3, 004. 
- Paugam, L., P. Astolfi, and O. Ramond. (2015). Accounting for business combinations: Do purchase price allocations matter?. Journal of Accounting \& Public Policy, 34 (4), 362-391.

- Ramanna, K., \& Watts, R. L. (2012). Evidence on the use of unverifiable estimates in required goodwill impairment. Review of Accounting Studies, 17(4), 749-780.

- Shalev, R., Zhang, I. X. \& Zhang, Y. (2013). CEO Compensation and Fair Value Accounting: Evidence from Purchase Price Allocation. Journal of Accounting Research, 51, 819-854. 